\title{
Data on the social network of peregrines from Brasov on occasional printed papers from the early modern era**
}

\author{
Andor Nagy*
}

Eszterházy Károly Egyetem

ORIGINAL RESEARCH PAPER

Received: November 24, 2020 • Accepted: February 1, 2021

Published online: June 16, 2021

(c) 2020 The Author(s)

\begin{abstract}
During their university studies the Saxons of Brasov, who used to be one of the most influential urban communities of Transylvanian Saxons, had relationships with friends and colleagues. I want to particularly highlight the relationships documented by the occasional prints between 1650 and 1750. I want to find the answer to what social circles are mentioned in the occasional prints related to the Saxon students of Brasov during their peregrination. Therefore I will henceforth mostly make attempts to reconstruct their friendly and collegial relationships.

Occasional texts transition between correspondences and few-word memorial notes (especially regarding the number of writers and the length of writings). Thus a comprehensive storing and analysing of the occasional works restricted to a certain group can provide an opportunity to get informed about family, friendly and collegial relationships. Such writings may also contain valuable implications for the research of relation history. The relations that can be seen through these might add a lot in terms of success, especially if it is possible to continue the relation historical exploratory work connected to certain people. Furthermore, these data can be compared with their positions held during a later period of their lives, as well as with their family relations and high reputation within their community.
\end{abstract}

\section{KEYWORDS}

social history of Transylvania, Transylvanian cultural history, book history, network analysis

\footnotetext{
*Corresponding author. E-mail: nagy.andor@uni-eszterhazy.hu

** Completion of this study was supported by the project EFOP-3.6.1-16-2016-00001 „Kutatási kapacitások és szolgáltatások komplex fejlesztése az Eszterházy Károly Egyetemen” [Complex Development of Research Capacity and Services at Károly Eszterházy University].
} 
During their university studies the Saxons of Brasov, who constituted one of the most influential urban communities of Transylvanian Saxons, maintained relationships with friends and colleagues. In this paper I wish particularly to highlight the relationships documented by occasional prints $^{1}$ dating to between 1650 and 1750 . The choice of the subject matter and also the setting of the time period were inspired by several factors. First of all, I was motivated to carry on the reconstruction $^{2}$ of the Transylvanian Saxon institutional and private libraries which ended in the early 2000's, since that effort did not include the Transylvanian occasional prints from the early modern era due to the nature of the genre. Secondly, the type of source implied is a less wellknown field of research in cultural and social history ${ }^{3}$. The reason for this is that no one so far has undertaken to explore occasional printed papers exhaustively, relating them to a particular community and then expanding the functional exploration with an analysis from the perspectives of cultural and social history. ${ }^{4}$ However, I must mention that Károly Szabó, among others, also started to review these records in the series called Régi Magyar Könyvtár (Old Hungarian Prints, henceforth abbreviated: RMK). In another series, Magyarország bibliographiája (Bibliography of Hungary), Géza Petrik made an effort to offer an exhaustive list related Hungarica prints. Since then not only have these works come to light, but a whole line of documents published since the beginning of national typography (1473) up to 1670 have been elaborated by the editors of the volume series Régi Magyarországi Nyomtatványok (Old Hungarian Prints, henceforth abbreviated: RMNY). Even so, as regards the occasional prints of a certain community, no exhaustive investigation has been carried out yet.

For that very reason, publishing the results of the present study was preceded by some basic research in which I focused on Saxon occasional writings from the early modern era, essentially based on the materials of the cartulary of the Black Church of Brasov (Evangelische Kirche A. B. Kronstadt - Archiv und Bibliothek der Honterusgemeinde). The study was based mostly on the collection which once formed part of the private property of Joseph Franz Trausch (1795-1871) a literary historian of Brasov. A significant but hitherto little known part of that collection consists of the records related to several different events and occasions, which I have completed along with some occasional works besides the Trausch collection of the archives, ${ }^{5}$ as well as with the materials of the National Archives of Brasov County (Arhivele Naționale ale României Filiala Braşov), the County Historic Museum of Brasov (Muzeul Judeţean de Istorie), the

\footnotetext{
${ }^{1}$ Especially during the early modern era, mentioning the members of a community on famous occasions mostly in verse form was a thriving tradition. These records are generally referred to as occasional prints that include writings created for one-time occasions. Typically such occasions were birthdays, graduations, weddings, inaugurations, promotions or deaths. This genre also involves documents that are cyclical, e.g. calendars, prognostications etc., which are not being discussed here. See occasional prints in detail: Stockhorst, 2006. 354-362; Münch, 2006. 1151-1160; Heltai, 2008. 257271; Wirth-Poelchau, 1990. 39-40.

${ }^{2}$ See results: Monok-Ötvös-Verók, 2001; Monok-Ötvös-Verók, 2004.

${ }^{3}$ See this in detail: Nagy, 2019a. 59-101.

${ }^{4}$ Due to this consideration in my doctoral dissertation I undertook the task of gathering all the occasional prints related to the Saxons of Brasov and of analysing them from a social historical (relation historical) point of view. See Nagy, 2019a. (The dissertation is available in the repository of Károly Eszterházy University: http://disszertacio.uni-eszterhazy. hu/69 - Latest download 10/05/2020.)

${ }^{5}$ I found two such groups of materials labelled with the archive marks below: Archiv der Honterusgemeinde Kronstadt (henceforth abbreviated: AHG) IV.F.97. and AHG IV.F.248.
} 
Brukenthal Museum in Sibiu (Muzeul Naţional Brukenthal), and also with those related to the Saxons of Brasov found in the National Széchenyi Library and the Library of the Hungarian Academy of Sciences. I compared the bibliography created in this way to the volumes of the Hungarian retrospective national bibliography, namely to the volumes of RMK and RMNY, and also to the lisu of works proposed by Géza Petrik, Julius Gross, Oskar Netoliczka, Mariana Iova, Ádám Hegyi and Attila Verók. I also indexed the bibliography as concordance for those works ${ }^{6}$. The dates contained in my work were established on the basis of topographic history; I started setting forth the matter from the 1650's onwards as occasional studies about the Saxons of Brasov are available from that period. Regarding the questions of the investigation, I decided to take the time span of a century to be able to analyse the data in a broader timeframe, through four generations.

While doing my research I noticed how colourful and versatile the topics of the works were, of the abundance of personal names in the texts and also of the possibility of making a map of the multi-fold relationships between the persons mentioned in the documents. In my essay I have been trying to prove the third of those aspects. First of all I want to show in a spirit of experimentation what the texts intended for others show when they are charted out as a network. Later on the results attained here can be linked with the data on contact history gained from further types of sources and hereby we will have a fuller picture of the 17th and 18th century intellectual community in Brasov.

In my work I want to find the answer to what social circles are mentioned in the occasional prints related to the Saxon students of Brasov during their peregrination. Therefore I will henceforth mostly make attempts to reconstruct their friendly and collegial relationships.

It is worth briefly touching upon the fact that, as a rule, friendly relationships are less attested and, for this very reason, in the absence of adequate sources they can be more doubtful too. The common form of this is a reconstruction based on correspondences. On the other hand, we have also been able to see examples of mapping friendly relations with the help of old books ${ }^{7}$ and albums amicorum ${ }^{8}$. Research networking based on occasional writings, however, is little known. Occasional texts vary between correspondences and few-word memorial notes (especially regarding the number of writers and the length of writings). Thus a comprehensive storing and analysing of the occasional works restricted to a certain group can provide an opportunity to get informed about family, friendly and collegial relationships. Such writings may also contain valuable implications for the research of contact history. The relations that can be seen through these might add a lot in terms of success, especially if it is possible to continue the exploration of contact history with regard to certain people. Furthermore, these data can be compared with the positions they held during later periods of their lives, as well as with their family relations and high reputation within their community. However, before turning to analysing the relationships of the Saxons of Brasov, I consider it well worth seeing the destinations of peregrination.

\footnotetext{
${ }^{6}$ The bibliography of the occasional writings of the Saxons of Brasov has been published recently in the Appendix of my doctoral thesis. In the current study I am also referring to its consignment numbers in order to complete correct identifications and provide greater traceability. The bibliography can be found in the Appendix of my previously mentioned thesis. See Nagy, 2019a. 207-457.

${ }^{7}$ Boveland, 2015. 97-118.

${ }^{8}$ Markó, 2018. 55-82.
} 


\section{THE DESTINATIONS OF THE PEREGRINATION FROM BRASOV}

It is a well-known fact that for the Hungarian protestant students of early modern times - for want of a national university - the possibility of studying at university entailed foreign peregrination. For Lutherans, peregrination at this time mainly centralised on the Upper Hungarian and Transylvanian Saxons, mining towns and cities with German-speaking inhabitants, and partially on the Slovaks and the Hungarian nobility. It became a common experience for young people having finished evangelical lyceums to go on with their studies at the Lutheran universities of the Holy Roman Empire. The most outstanding among those was Wittenberg University, where, among many others, Martin Luther and Philipp Melanchton (1497-1560), the two dominant personalities of Reformation taught. By the end of the $16^{\text {th }}$ century the important German universities of the time such as those of Tübingen, Leipzig, Frankfurt an der Oder, Greifswald, Heidelberg, Rostock, Jena, Marburg and Königsberg ${ }^{9}$ had been converted to the image of Wittenberg University. These are the universities the Hungarian Lutheran students were studying in at that time.

Today the rate students who attended foreign universities can be traced quite well relying on published registers and peregrination catalogues as long as we are able to identify properly the people represented by the particular personal names. Good resources for this purpose include both registers and occasional prints from Brasov. Research into university history completed so far shows that the number one target destination for Hungarian protestant students was Wittenberg University, which was becoming a stronghold of orthodoxy for the Lutheran Church in the $16-17^{\text {th }}$ centuries. Then, in 1694 , Halle University was established and later, in 1734 university education started in Göttingen. These institutions came to occupy an absolutely central role and pushed Wittenberg University into background. ${ }^{10}$

The vast majority of the Transylvanian intelligentsia consisted of pastors and teachers who had studied at foreign universities and who, as a rule, returned home after graduation. ${ }^{11}$ Most young people applied to study theology with the purpose of laying the foundation for the career as a pastor. However, quite a few of them acquired legal or doctoral qualifications (as well). ${ }^{12}$

Although the institution of peregrinatio academica has by now become one of the best known areas of European cultural history, we have little knowledge of the occasional writings created during the period of going to foreign universities. The students who had studied abroad could establish their later careers in this country not only thanks to their qualifications, but also through building contacts. These documents shed light on the literary and poetic work they carried out, and this confirms that they cultivated emerging friendly relations with other students. The relationships are shown in the students' personal poems even more vividly than in the records of the albums amicorum created at the same time. We must also add some further conclusions that have become clear in the specialised literature through earlier observations. There is a procedure that can be considered problematic. Contrary to its medieval pre-formations it adopts some typical conclusions about attending universities in Transylvania in the early

\footnotetext{
${ }^{9}$ Balázs-Bitskey-Ötvös [et al.], 2009. 126-127.

${ }^{10}$ Balázs-Bitskey-Ötvös [et al.], 2009. 127.

${ }^{11}$ In the $16-17$ th centuries no more than $2.4 \%$ of the known Transylvanian students stayed abroad. cf. Péter, 1988.767.

${ }^{12}$ Kecskeméti, 2014. 18-19.
} 
modern era without criticism, i.e. it claims that the academics of the time began to play important roles in cultural and social history only after returning home. ${ }^{13}$ Sources, however, reveal that there were plenty of people who were acting as examiners, prose-writers or poets even while stationed abroad.

\section{THE CIRCLE OF CONTACTS OF THE PEREGRINES OF BRASOV}

Joining the range of works written on contact history earlier, I am analysing the circle of contacts which represents the élite of the community of Brasov as follows. English and German historiography have produced significant results in seeing these relations in their totality and also in their visualisation, therefore I mainly wish to rely on those results. In the set of works on relation history we may find an early investigation method by German historian Wolfgang Reinhard, which my research links to in terms of its logic. Reinhard did pioneering work in mapping out fully the contacts connecting the élite which once ruled the politics of the papal court (Fig. 1). ${ }^{14}$

In networks, the individuals are usually seen as nodes, while the relations are represented as edges. As regards the social networks that are included in this analysis, they symbolise the people inspected and their relations. In his above mentioned work Reinhard made attempts to analyse the linking zones between the individuals, which are generally called 'intervals' or 'steps'. For example, in the figure above (Figure 1), Johann Albrich is two steps (or intervals) removed from Mátyás Bél, Michael Euser and Johann Klein. But due to his contact with them he is three steps away from Samuel Herrmann, Johann Krempes and Martin Kelp. The number of steps is one of the most important marks of a network, as it allows us to get the picture of the existing intervals between the members of a community and also of the interconnection of the group.

The most significant feature of networks is degree, which indicates the number of relations between a node and the other nodes of the network. ${ }^{15}$ Degree has two types: in-degree and

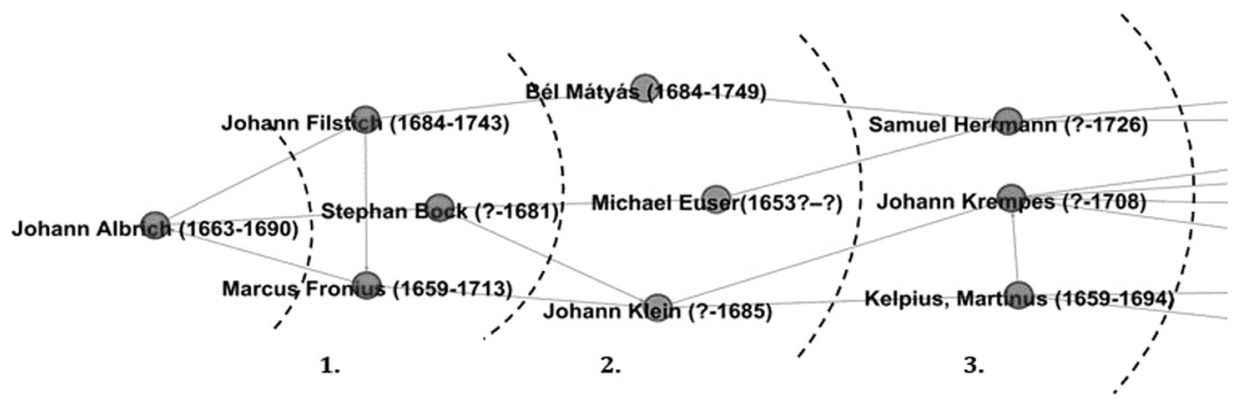

Fig. 1. Steps and linking zones

\footnotetext{
${ }^{13}$ cf. Tonk, 1979. 121; Szabó-Szögi, 1998. 35.

${ }^{14}$ Most of his works deal with the fundamental conceptions and methodology of social network analysis. See in detail Reinhard, 1979. 9-41.

${ }^{15}$ Reinhard, 1979. 27; Barabási, 2016. 61, 82.
} 
out-degree. In-degree shows the number of relations coming to the investigated node. Here it indicates, e.g., how many of them wrote poems of congratulations on someone's dispute or how many paid their last respects to a deceased person in the occasional prints created in their honour. On the other hand, out-degree shows how many edges proceed from a certain node, i.e. for example how often a particular person wrote an occasional poem and to which or his fellow students during their university studies. If we have a closely woven network, the average degree can be determined, which is the average of the total of the in- and out-degrees. ${ }^{16}$ This reveals, for instance, what individuals in a community were written to and how often. The importance of such data is that by knowing it we can also learn about the reputation of individuals among the members of a community. The simplest prestige-indicator is degree prestige, when we add up the relationships pointing to a certain person. ${ }^{17}$ In this respect, people who were chosen by many (e.g. got congratulations) can be regarded as being of high reputation. Thus the degree prestige of an individual is equal to the in-degree of that particular person.

As for personal career achievements, we must also place a high value on what kind of relations and with whom the future pastors and council members of Brasov maintained during their university years, and whether the relations registered here could have an impact on their positions taken later in their lives. A further question arises whether there were some academics who were treated with more respect than others, and whether this was also manifested on the pages of occasional writings. ${ }^{18}$ These pieces of information also shed light on the prestige value of families, according to which there is reasonable ground to believe that it was in the interest of the less famous to get in closer touch with them, or to stay close by during the years when they shaped their later careers. To answer these questions we need to see what relation circle the peregrines developed with regard to the community analysed. My further study will be focusing on the individuals that are connected to the occasional prints, mainly disputes, graduation speeches, congratulations on name days, passing away and departures written during their peregrination.

Earlier research on university history claimed that the greatest number of people who went to study at foreign universities were patricians from Brasov and Sibiu. They were also authors of some occasional works, but we do not have an overall investigation on this. On the other hand the Transylvanian peregrination data stores hallmarked with the names of Miklós Szabó, László Szögi and Sándor Tonk can be regarded to this date as the most relevant starting point for investigations of this kind, since the related bibliographies in RMK [Old Hungarian Library] Vol. 3 had consistently been marked among the registers containing biographies. ${ }^{19}$ The details

\footnotetext{
${ }^{16}$ Barabási, 2016. 63-65.

${ }^{17}$ Kürtösi, 2011. 25.

${ }^{18}$ I.e. a greater number of them received congratulations messages or people congratulated them several times on one specific occasion.

${ }^{19}$ In fact, implications for biography recoverable from these were also made use of. See Szabó-Tonk, 1992; Szabó-Szögi, 1998. Certainly these data stores cannot substitute re-checking the texts or the relevant individuals one by one, because it does happen on rare occasions - especially when there are name matches - that the biographical details and/or the RMK (see Szabó-Hellebrandt, 1896-1898.) numbers of the individuals are found jumbled in the data store. cf. for example: Szabó-Tonk, 1992, Descriptions No. 170. and No. 221, where the biographical details and the RMK numbers of Andreas (I.) Bogner (1640-1719) and his son, Andreas (II.) Bogner (1678?-?) got mixed up. Similar mistakes can be corrected by doing re-checks.
} 
revealed here can now be made more complete by adding the supplements of RMK Vol. 3, with additions concerning the $18^{\text {th }}$ century, with "Petrik volumes" (the materials of which the editors of the catalogues did not put in their synoptic studies) and also with the related bibliographies having been published since then. ${ }^{20}$

Based on the available bibliographical facts and figures we are now able to reconstruct friendly affiliations suggestive of schoolmate, fraternal and even of patronage relations. From these it becomes evident that peregrination was a really significant period for the patrician citizens of Brasov in terms of their future career not only for their graduation but just as much for expanding and deepening connections.

The figure below (Figure 2) shows the circle of writers speaking highly of one another in network formation drawn with the help of the social network analysis software Gephi. ${ }^{21}$ Each person mentioned in the occasional writings related to the Saxons of Brasov is there, and every individual is included just once. It is clear that amicable relationships have been arranged in one big and several smaller network groups. Also, it is worth mentioning that it was not known earlier that this tradition of community commemoration presents the picture of a closely woven network, too. ${ }^{22}$ Seeing this in such a form, however, convinces us of the tight cohesion of the community of the period intelligentsia.

I have classified networks into four groups. In the first I included the individuals seen in the prints made at Wittenberg University and their relations, whereas in the case of the other three groups we can explore relations to the group by attributing greater significance to certain group characteristics than to social background. The figure also shows (Figure 2) some smaller networks which include the related individuals and their prints. These people form the circle of occasional authors connected not to Wittenberg but to other universities with far fewer students, or where no prints related to students from Brasov were created (or been discovered so far).

The network marked with Figure 1, the most extensive of all, represents the authors and the titles of the prints related to the years spent at Wittenberg University. Besides common, fraternal or schoolmate relationships it also represents closer ties. This group contains 421 relations of 233 individuals, where the people represented come from the following backgrounds: Brasov 76 (33\%), other Transylvanians 108 (46\%), Germans 39 (17\%), Hungarians from Royal Hungary 10 (4\%). These numbers are exclusively the results gained by mapping the university relationships of the Saxons of Brasov (Burzenland).

The dimensions of the nodes seen in Figure 2 show the number of relationships (i.e. the degrees). The more relations someone has in the print, the higher their degrees are. This is important because this number is notable considering the prestige value within a particular community and points to the individuals to whom others wrote in highest numbers. The bond with the community is shown by the total number of occurrences of a name (in-degree) and as

\footnotetext{
${ }^{20}$ Ernst Wagner's register does not provide appropriate detail in this respect, as, on the one hand it lists only the evangelical pastors and teachers up to 1700 , on the other hand it contains nothing about the careers of the authors in question. See Wagner (Hrsg), 1998

${ }^{21}$ Gephi is a social network analysis programme, an open-source network analysis and visualization software package, which allows us to visualize all kinds of large-scale graphs and networks.

${ }^{22}$ The general network definition of a community is when some of the group members are connected by more edges within the network than to other nodes.
} 


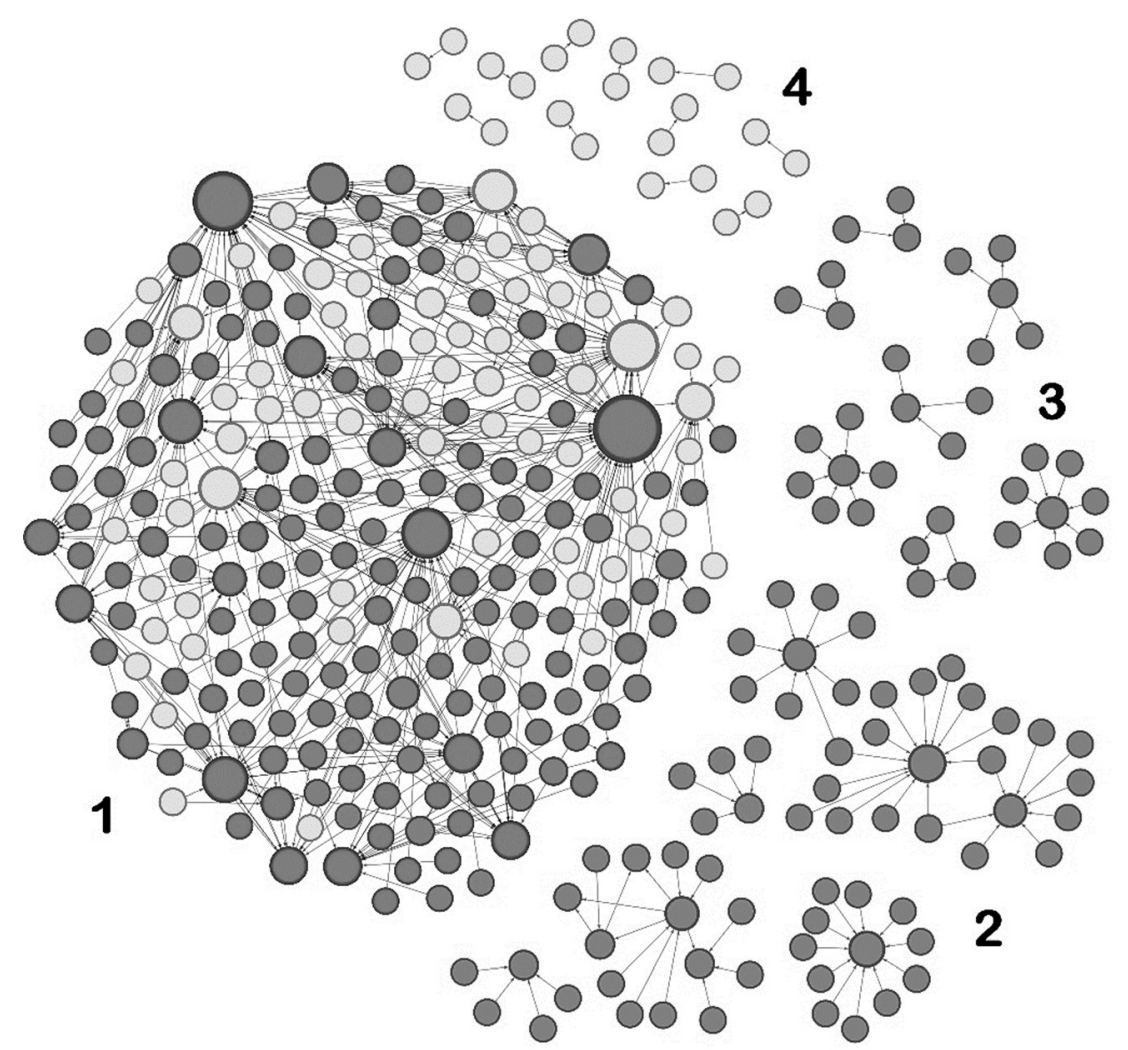

Fig. 2. Authors and individuals lauded in the occasional prints made during peregrination (1650-1750)

author (out-degree) of the distinguished person in the print. According to the degrees the ranking of the first 20 individuals is as follows (Table 1):

When comparing the numbers of the authors and distinguished persons, a conspicuous difference may be noted. The tradition of celebration and commemoration seems to focus on a few individuals, consequently the number of congratulatory writings among the fellow students is not identical. The first half of the list can boast a much wider circle of respecters than the persons coming next. As for the author's side, the group of distinguished people is more divided. However, it is also clear here that the highest number of authors can be found among the most highly respected individuals.

After we have seen the virtues of the network, we now also have the opportunity to compare them with the later careers of some individuals. As we can state, in terms of degrees Marcus Fronius (1659-1713), coming from a pastor's family of Keresztényfalva \{Hungarian; Cristian Romanian\}, built the biggest social reputation. Having returned home after his peregrination, he started getting higher in the office hierarchy quite fast. He was secondary school teacher for merely two years, after that deacon of the Black Church for three years. Then he was appointed to be pastor of Höltövény (Hungarian; Halchiu - Romanian), of Barcarozsnyó (Hungarian; 
Table 1. The degrees of the Saxons of Brasov regarding their disputes

\begin{tabular}{|l|c|c|c|c|}
\hline & Names & Distinguished Person & Author & $\Sigma$ (degree) \\
\hline 1. & Marcus Fronius (1659-1713) & 37 & 9 & 46 \\
\hline 2. & Johann Albrich (1663-1690) & 30 & 7 & 37 \\
\hline 3. & Theodorus Mederus (1663-1688) & 27 & 0 & 27 \\
\hline 4. & Johann Francisci (1665?-1696) & 16 & 6 & 22 \\
\hline 5. & Christoph Greissing (1664-1686) & 21 & 0 & 21 \\
\hline 6. & David Czako (1641-1681) & 18 & 0 & 18 \\
\hline 7. & Paul Teutsch (1665?-1719) & 11 & 4 & 15 \\
\hline 8. & Johann Abrahami (1668?-1705) & 12 & 2 & 14 \\
\hline 9. & Marcus Draudt (1665-1724) & 10 & 3 & 13 \\
\hline 10. & Andreas Tartler (1663-1688) & 5 & 3 & 8 \\
\hline 11. & Valentin Greissing (1653-1701) & 3 & 4 & 7 \\
\hline 12. & Lucas Römer (1663-1721) & 1 & 5 & 6 \\
\hline 13. & Johann Draudt (1649-1720) & 5 & 0 & 5 \\
\hline 14. & Valentin Gockesch (?-1691) & 2 & 3 & 5 \\
\hline 15. & Paul Neunachbar (?-1667) & 3 & 0 & 3 \\
\hline 16. & Paulus Chrestels (1650?-1689) & 2 & 0 & 3 \\
\hline 17. & Michael Bell (?-1692) & 0 & 1 & 3 \\
\hline 18. & Martin Albrich (1661-1682) & 1 & 0 & 1 \\
\hline 19. & Marcus Mankesch (1670-1692) & 1 & 1 \\
\hline 20. & Petrus Sturm (?-1707) & & 0 & 1 \\
\hline
\end{tabular}

Rasnov - Romanian) and in the end, at the age of 44, of Brasov. After that he became dean of the Burzenland and thus he reached the top of his career.

In terms of degree, the second person in line is Johann Albrich (1663-1690). We are informed about his departure to return home from Wittenberg in October $1685 .^{23}$ At one point he was appointed to be teacher of his former grammar school but he passed away at a young age on November $14^{\text {th }} 1690$, after four years working as a "lector". His death was commemorated even in the position of lector, which shows how much he was respected by the society of Brasov. ${ }^{24}$

In terms of degrees, in the third place we find Theodor Mederus (1663-1688). Speaking of him, it is worth mentioning that his early death was commemorated owing to his father, who

\footnotetext{
${ }^{23}$ Szabó-Hellebrandt, 1896-1898. no. 3377.

${ }^{24}$ See Nagy, 2019a. No. 203. Besides him, the only person commemorated as a lector was Joseph Bolthosch. cf. Nagy, 2019a. No. 310.
} 
had acquired international fame (poeta laureatus). ${ }^{25}$ His premature death also explains why we have no surviving writings by him. ${ }^{26}$

Johann Francisci (1665?-1696) from Brasov had no renowned ancestors, therefore we have reason to consider his high rank out of place. He probably occupied this position due to having a good relationship with fellow-students coming from prestigious families of his time. The prints reveal that he congratulated Marcus Draudt (1665-1724) ${ }^{27}$ and Paul Teutsch (1665?-1719) on publishing their disputes ${ }^{28}$ and, on the other hand, he wrote farewell poems for the funerals of his fellow students such as Christoph Greissing (1664-1686) ${ }^{29}$ and Andreas Tartler (1663-1688). ${ }^{30}$ Quite a few people, including those mentioned above, congratulated him on his disputes and graduation in their writings. Unfortunately, he also died during his "lector" phase, so his promising career never actually unfolded.

$\mathrm{He}$ is followed by academic members from the Greissing, Czako, Teutsch, Draudt and Tartler families. It is not surprising either that, except for the already mentioned individuals, they had the most outstanding relation rates as compared to the others (76 individuals from the Burzenland area). All of them had outstanding ancestors among officials and the Church elite. The only exception is Paul Teutsch (1665?-1719), in whose case we cannot speak of a similar ancestry. Presumably, however, he himself managed to become a member of the Church elite through his relations and to keep this up effectively for his children, too. ${ }^{31}$ The other exception is Johann Abrahami (1668?-1705), who cannot be found among the children of the patrician families, yet he can boast a significant number of relations of merit. His father was pastor of Szászsáros [Hungarian; Saros pe Tarnave - Romanian], and as a student in Brasov he wrote a poem together with Theodor Mederus commemorating marriages between members of the prestigious Herrmann, Honterus and Hirscher families.

Abrahami was to say a farewell to Johann Chrestel, secretary of Brasov (1653-1686) from a patrician family by reading a poem at his funeral that he had written for the occasion. ${ }^{32}$ All in all, these relationships are related to the later careers of the academics in question.

In group No. 2 we can see the circle of relations formed around six persons with their origins in Brasov. Two of them, Andreas Henning (1643-1710) and Johann Kraus (1640?-1655) have four contacts each. After finishing his studies in Strasbourg, Henning performed his "dispute" on natural law in Jena in November $1666,{ }^{33}$ and received the congratulations of Georg Sattler

\footnotetext{
${ }^{25}$ This is confirmed by his biographical summary containing details of his family background and published together with his burial farewell message.

${ }^{26}$ However, before his peregrination he had written a funeral farewell poem in Brasov (Nagy, 2019a. No. 156) and a wedding congratulation (Nagy, 2019a. No. 145) is.

${ }^{27}$ Nagy, 2019a. No. 157.

${ }^{28}$ Nagy, 2019a. No. 172.

${ }^{29}$ Nagy, 2019a. No. 152.

${ }^{30}$ Nagy, 2019a. No. 185.

${ }^{31} \mathrm{cf}$. Jekelius, 1966. 136-140.

${ }^{32}$ cf. Nagy, 2019a. No. 145. and Nagy, 2019a. No. 156. Biographical details see Szabó-Tonk, 1992. No. 1436; Wagner (hrsg.), 1998. No. 130.

${ }^{33} \mathrm{cf}$. Nagy, 2019a. No. 58. There were no students from Brasov at the University of Jena this time. cf. Herfurth-Schiel, 1875. 316-319.
} 
(?-1691) from Beszterce [Hungarian; Bistrita - Romanian], Lucas Herrmann (?-?) from Berethalom [Hungarian; Biertan - Romanian], Jeremias Johannis (?-?) from Nagyszeben [Hungarian; Sibiu - Romanian] and Petrus Honnius (?-?) from Medgyes [Hungarian; Medias Romanian]. The person in the centre of the next network is Johann Kraus. His death after his university studies was commemorated by his fellow pastors from Jördensdorf, Thürkow, Altkalen and Levetzov (Lübow) in the city of Güstrow. ${ }^{34}$

Paul Francisci (1645?-1711), who studied medicine at the University of Strasbourg and the University of Altdorf, makes up a separate group. His circle of friends related to the universities can be reconstructed through three prints. ${ }^{35}$ Samuel Draudt (1706-1739) a physician stands in the middle of a further group. His dispute took place in Halle in 1734, which was commemorated in two prints. ${ }^{36}$ In the same network with him we find Stephan Closius (1717-1781) who also "disputed" in Halle as a physician six years later in $1740 .{ }^{37}$ The connection between them (the bridge in the network) is made by a professor of medicine, Friedrich Hoffmann (1660-1742), who was a teacher of both of them and expressed his congratulations to them. The last network in the group is made up by Joseph Gottlieb Seuler von Seulen's (1727-1746) circle of friends, who came from a patrician family and passed away in his years of studying law at the University of Jena. Three burial speeches were written in his honour. ${ }^{38}$

In group No. 3 I have placed the networks with fewer registered relationships. The obvious reason for smaller networks is that some academics from Brasov travelled to places and recorded events in which they had taken part which most of other their compatriots did not attend. Here we may notice that individuals from Brasov more typically appear as authors, therefore their individual relations come to the front. This is attested by the writings of Johann Filstich (1684-1743), a student from Brasov who attended the dispute of Mátyás Bél (1684-1749) in Halle in 1707, or of Paul Greissing (1633-1687), and congratulated Jacob Schaller (1635?-?), a student from Strasbourg in the form of poem. We may likewise refer to the congratulatory message written by Johann Fuchs (1631-1686) and Georg Hermann (1598?-1653), two students from Brasov, for the dispute of a theology student at Wittenberg called Johann Fabiger (1630?-?).

In group No. 4 I have indicated the authors and distinguished persons recorded with one relation each. This circle further constricts the amount of prints showing individual relationships. The events that come into prominence here are more personal in nature, and affect only two people. One such typical event was departure; e.g. the texts written to commemorate Georg Dietrich's departure home from Wittenberg ${ }^{39}$ and Georg Clomp's (1723-1782) or Johann

\footnotetext{
${ }^{34}$ Nagy, 2019a. No. 54.

${ }^{35}$ Szabó-Tonk, 1992. No. 2234; Trausch, 1868-1871. I. 336. Prints: Nagy, 2019a. No. 61, 97-98. Of the doctoral studies of Transylvanian academics at German universities see in detail Offner, 2006. 287-343. Of Francisci's unique collection of specialised textbooks see Verók, 2012. 307-320., and of his role in cultural history see Verók, 2018. 445-456.

${ }^{36}$ cf. Nagy, 2019a. No. 386. Biographical details see Trausch, 1868-1871. I. 266; Szabó-Szögi, 1998. No. 950; Quellen 1919. V. 621. He was buried by a collapsing building being pulled down. See Nagy, 2019a. No. 387.

${ }^{37}$ His doctor of medicine dispute remained (Nagy, 2019a. No. 428.), so did his congratulations written for this occasion (Nagy, 2019a. No. 429.) and also his print recording the fact of getting a degree (Nagy, 2019a. No. 430.). Biographical details see Gusbeth, 1884. 62-63; Petrik, 1888-1892. I. 426; Szabó-Szögi 1998. No. 679; Trausch, 1868-1871. I. 225.

${ }^{38}$ cf. Nagy, 2019a. No. 473, 476-477. Biographical details see Szabó-Szögi, 1998. No. 3663; Trausch, 1868-1871. III. 299.

${ }^{39}$ Nagy, 2019a. No. 242.
} 
Meilmein's (1720?-?) from Görlitz ${ }^{40}$. Another typical event was graduation; e.g. the prints created to commemorate Johann Honterus's (1633-1691) ${ }^{41}$ or Michael Girald's (1720?-?) MSc graduation. ${ }^{42}$ Ennoblement is also a case in point here; e.g. Michael Fronius's (1675-1728) congratulations message written in Leipzig in honour of one of his compatriots, Georg Czako $(1661-1726)^{43}$.

\section{RESUME}

In this paper I have made attempts to reconstruct the friendly and fraternal relationships of upper class Saxons from Brasov with the help of occasional prints. The main reason for this was that this type of source is a less known area of relation history research. On the other hand, a question arose during the research: could there be academics who were more prestigious than others, and if so, was that expressed in the occasional prints. ${ }^{44}$ Based on the results of the research outlined above, the answer is definitely yes. When comparing the numbers of authors and distinguished persons, there is instantly a marked difference to be noticed: the number of congratulatory writings is not the same among fellow students. This means that the tradition of celebrating and commemorating seems to centre on a few individuals. Although among the authors the group of persons with higher relation values is more split, it is also remarkable that the most authors are among those who receive the highest respect. In the first place we find the youth of the most outstanding families of Brasov, the Fronius, Albrich, Mederus, Greissing etc. families. All this has shown us the prestige value of the families according to which there is reasonable ground to believe that it was in the interest of the less famous families to get in closer touch with them during the time when they were to shape their later careers. In order to find out more about this area I looked at the related individuals of the occasional prints written during peregrination, mainly of the commemorations for disputes, graduations, passing away, departures and congratulations on name days. During the research the method of network analysis has been proved well adaptable and it made not only the visualisation but the description of the relationships simpler.

The conclusions drawn during further investigation become clearest when comparing them to the career fulfilment of the individuals in question. In my opinion it is really significant what relations and with whom the future pastors and council members of Brasov maintained during their university years. The relations recorded could have an influence on their later positions, and the observation of these may bring new correlations to light in the future.

In addition the study has made the case for revealing the relational circle manifested during the peregrination of the Hungarian intelligentsia based on the collection of old books related to the Hungarika as a whole [the National Archives of Hungary]. This strand of research

\footnotetext{
${ }^{40}$ Nagy, 2019a. No. 445.

${ }^{41}$ Nagy, 2019a. No. 32.

${ }^{42}$ Nagy, 2019a. No. 480.

${ }^{43}$ Nagy, 2019a. No. 250.

${ }^{44}$ I.e. a greater number of them received congratulatory messages or people congratulated them several times on one specific occasion.
} 
comparing later the career paths, would provide opportunities to make observations of a previously unprecedented nature. The period of peregrination can also be connected with the relations found in albums amicorum, which would add further nuance to the picture we have established regarding the relationships of these intellectuals. To these we can add the results of the research concerning collections of private libraries, which, in fact, cover the entire range of cultural and scientific relations. ${ }^{45}$ The variety of available sources can be expanded by involving documents kept in other foreign and national archives. What is more, the elaboration of the documents would be supported by different IT possibilities available (Nagy, 2019b). Thus applying this type of source in the future we can hope to reveal further, previously unknown correlations for historical network research.

\section{REFERENCES AND ABBREVIATIONS}

\section{ARCHIVES SOURCES}

Jekelius, E. (1966). Genealogie Kronstädter Familien. [The geneology of families of Kronstadt] Kronstadt, [Typescript], VIII. Shelf number: AHG IV.F.57.

\section{SPECIALIST LITERATURE}

Balázs, M., Bitskey, I., Ötvös, P., and Viskolcz, N. (2009). Entry „Peregrination”. In: Kőszeghy, P. (Ed.), Magyar müvelödéstörténeti lexikon I. Középkor és kora újkor. [Encyclopedia of Hungarian Cultural History 1. The Middle Ages and the early Modern Times], Balassi Kiadó, Budapest, pp. 123-131.

Barabási, A.-L. (2016). A hálózatok tudománya. [The science of networks], Libri Kiadó, Budapest.

Boveland, C. (2015). Wer kennt wen? Versuch der Rekonstruktion von Bekanntschaftsnetzwerken aus Daten des VD 17 [Who knows whom? Attempt to reconstruct the network of acquaintances based on the data of VD 17]. Wolfenbüttler Notizen zur Buchgeschichte [Notes by Wolfenbüttler on Book History], 40: 1-2. sz. 97-118.

Kecskeméti G. (2014). Értelmiségi pályák a kora újkori Magyarországon: a tipikus és az egyéni. [Careers of intellectuals in hungary of early modern times: Typical and individual]. In: Biró, A., and Boka, L. (Eds), Értelmiségi karriertörténetek, kapcsolathálók, írócsoportosulások. [Career stories of intellectualls, relation networks, writers' clusters], Partium Kiadó - Reciti, Nagyvárad-Budapest, pp. 13-30.

Kürtösi, Z. (2011). A társadalmi kapcsolatháló-elemzés módszertani alapjai [Methodological fundamentals of social relation network analysis]. In: Takács, K. (Ed.), Társadalmi kapcsolathálózatok elemzése [Analysis of social relation networks], BCE Szociológia és Társadalompolitika Intézet, Budapest, pp. 19-31.

Heltai J. (2008). Müfajok és müvek a XVII. század magyarországi könyvkiadásában (1601-1655) [Genres and Works of Hungarian Publishing in the 17th century], Universitas, Budapest, (Res Libraria, 2.).

${ }^{45} \mathrm{cf}$. Monok, 2010. 154-155. 
Herfurth, F., and Schiel, G. (1875). Verzeichniß der auf der Universität zu Jena immatriculirten Ungarn und Siebenbürger [The register of Hungarians and Transylvanians enrolled at the university of Jena]. In: Ausschuß, V. [Hrsg.], Archiv des Vereines für Siebenbürgische Landeskunde. Neue Folge. Zwölfter Band. 2. Heft [The archives of the Transylvanian local history association. new series.Vol.2 Booklet], Hermannstadt, Gedruckt in der Buchdruckerei der v. Closius'schen Erbin, pp. 312-353.

Gusbeth, E. (1884). Zur Geschichte der Sanitäts-Verhältnisse in Kronstadt [To history of health care system of Brasov], Verlag des Verfassers [Eduard Gusbeth], Kronstadt.

Markó, A. (2018). Hálózatok a 16-17. századi album amicorumokban: az 1500 és 1700 közötti hungarika jellegü emlékkönyvbejegyzések hálózatelemzése az Inscriptiones Alborum Amicorum adatbázis alapján [Networks in Albums Amicorum: network analysis of Hungarica type album entries between 1500 and 1700 based on the database of Alborum Amicorum]. In: Digitális Bölcsészet [Digital liberal arts], Vol. 1, pp. 55-82.

Monok, I. (2010). A magánkönyvtárak és az olvasás a korai újkorban. Vázlat az elmúlt ötven év európai kutatástörténetéről [Private libraries and reading in the early modern times]. In: Magyar Könyvszemle [Hungarian book review], year 126 No. 2. pp. 141-157.

Monok, I., Ötvös, P., and Verók, A. (2001). Erdélyi szász intézményi és magángyüjtemények, 1578-1750. Könyvjegyzékek bibliográfiája [Institutional and private collections of the Transylvanian Saxons, 15781750. Bibliography of book lists], Scriptum Rt., Szeged, (Könyvtártörténeti füzetek, X. [Booklets of History of Library 10]).

Monok, I., Ötvös, P., and Verók, A. (2004). Erdélyi könyvesházak \{Transylvanian book houses\} IV/1-2 = Bibliotheken in Siebenbürgen IV/1-2. Lesestoffe der Siebenbürger Sachsen, 1575-1750. Bistritz, Hermannstadt, Kronstadt, Schäßburg, Kleinere Orte, Országos Széchényi Könyvtár, Budapest, (Adattár a XVI-XVIII. századi szellemi mozgalmaink történetéhez, [Database on the History of the Spiritual Movements of 16-18th centuries] 16/4.1-2).

Münch, R. (2006). „Druckmedien” [Printed Media] [encyclopaedia entry]. In: Friedrich J., and Weimar, S. (Hrsg). Enzyklopädie der Neuzeit [Encyclopedia of modern times], 4. Bd, Verlag J. B. Metzler, pp. 11511160 .

Nagy, A. (2019a). Érvényesülési stratégiák a brassói szász tisztviselök körében. Kapcsolatháló-elemzés és családrekonstrukció az alkalmi nyomtatványok segitségével [Strategies of Predominancy among the Saxon Officials of Brasov. Relation Network Analysis and Family Reconstruction with the help of Occasional Prints], PhD thesis, Eszterházy Károly Egyetem.

Nagy, A. (2019b). A digitalizált alkalmi írások kutatásának lehetőségei informatikai eszközökkel. In: Dániel B. (Ed.), Konferenciák, mühelybeszélgetések XVI. Hagyományos források, új megközelitések. A digitalizáció kinálta lehetöségek a történeti kutatásokban [Conferences, workshops 16. traditional sources, new approaches. opportunities provided by digitalisation in historical research], Líceum Kiadó, Eger, pp. 69-101.

Offner, R. (2006). Deutsche Universitäten als Ausbildungsstätten siebenbürgischer Mediziner von den Anfängen bis zum Jahr 1850 [German universities as centres of medical training in Transylvania from the beginning to 1850]. In: Márta, F., Gyula, K., and Anton, S. (Hrsg.), Peregrinatio Hungarica. Studenten aus Ungarn an deutschen und österreichischen Hochschulen vom 16. bis zum 20. Jahrhundert [Students from Hungary at German and Austro-Hungarian/Austrian Universities between 16 and 20 centuries], Franz Steiner Verlag, Stuttgart. pp. 287-343.

Péter, K. (1988). A fejedelemség virágkora [Heyday of principality] (1606-1660). In: Béla K. (Ed.), Erdély története [History of Transylvania] 1606-tól 1830-ig, Akadémiai Kiadó, Budapest. pp. 617-783. 
Quellen zur Geschichte der Stadt Brassó [Sources for the History of Brasov City]. V. Bd (1909). Herausgegeben auf Kosten der Stadt Brassó [Published at the expence of Brasov], Kronstadt. Kommission bei Heinrich Zeidner.

Petrik, G. (1888-1892). Magyarország bibliográphiája 1712-1860. Könyvészeti kimutatása a Magyarországban s hazánkra vonatkozólag külföldön megjelent nyomtatványoknak, I-IV. köt. [Bibliography of Hungary 1712-1860. Bibliographical Registry of the Prints published in Hungary and abroad with reference to our momeland, vol. 1-4], Dobrowsky Ágost - Pallas Részvénytársaság Nyomdája, Budapest.

Reinhard, W. (1979). Freunde und Kreaturen \{Friends and Clusters\}. „Verflechtung” als Konzept zur Erforschung historischer Führungsgruppen. Römische Oligarchie um 1600 [Intergrowth as Notion for the Research on the Leading Historical German Upper Class Groups], Verlag Ernst Vögel, München, (Schriften der Philosophischen Fakultäten der Universität Augsburg [Writings of the Faculty of Philosophy of the University of Augsburg], 14.).

Stockhorst, S. (2006). „Gelegenheitsdichtung” encyclopaedia entry [„Occasional Poems” entry]. In: Friedrich, J., Stuttgart, and Weimar (Hrsg.), Enzyklopädie der Neuzeit, Bd. 4. [Ecyclopedia of the modern times, vol. 4.], Verlag J. B. Metzler, pp. 354-362.

Szabó, K., and Hellebrandt, Á. (1896-1898). Régi Magyar Könyvtár III. Magyar szerzöktöl külföldön 1480tól 1711-ig megjelent nem magyar nyelvü nyomtatványok könyvészeti kézikönyve [Old Hungarian Library 3. Bibliographical Handbook of Prints by Hungarian authors published abroad and not written in Hungarian 1480-1711], MTA, Budapest.

Szabó, M., and Szögi, L. (1998). Erdélyi peregrinusok. Erdélyi diákok európai egyetemeken [The Peregrines of Transylvania. Transylvanian students at European universities], 1701-1849, Mentor Kiadó, Marosvásárhely.

Szabó, M., and Tonk, S. (1992). Erdélyiek egyetemjárása a korai újkorban [Transylvanian Peregrination in the early modern times], 1521-1700, JATE, Szeged, (Fontes Rerum Scholasticarum, 4.).

Tonk, S. (1979). Erdélyiek egyetemjárása a középkorban [Transylvanian Peregrination in the Middle Ages], Kriterion Könyvkiadó, Bukarest.

Trausch, J. (1868-1871). Schriftsteller-lexikon oder biographisch-literärische Denk-blätter der Siebenbürger Deutschen, I-III. Bd. [Writers' Cyclopedia or Biographical-Literary Remenbrance of the Transylvanian Germans vol. 1-3], Verlag von Johann Gött et Sohn Heinrich, Kronstadt.

Verók, A. (2012). A gyógyítás szolgálatában a Barcaságtól Frankóniáig. Paul Francisci orvosi könyvtárának jegyzéke a 18. század elejéről [In Ministry of Healing from Burzenland to Franconia. The Register of Paul Francisci's Medical Library from the beginning of the 18th century]. In: Kaleidoscope. Müvelödés-, tudomány-és orvostörténeti folyóirat. 3, [Kaleidoscope. Journal on Cultural and Medical History and History of Science 3.], p. 5.

Verók, A. (2018). Barcasági szász peregrinusok európai egyetemeken. Oktatás, könyvkultúra, tudomány [Saxon Peregrines of Burzenland at European Universities. Education, Culture of Bibliography, Science]. In: Kolumbán, V. J. (Ed.), A reformáció öröksége [The heritage of the reformation], Kolozsvári Protestáns Teológia Kiadója, Kolozsvár. pp. 445-456, Erdélyi Református Egyháztörténeti Füzetek, 24 [Booklets on the History of the Calvinist Church of Transylvania, 24].

Wagner, E. (Hrsg.) (1998). Die Pfarrer und Lehrer der Evangelischen Kirche A.B. in Siebenbürgen. I. Band: Von der Reformation bis zum Jahre 1700 [The Pastors and Teachers of the Evangelical Church in Transylvania. Vol. 1: From the Reformation to 1700], Köln-Weimar-Wien, Böhlau Verlag, (Schriften zur Landeskunde Siebenbürgens \{Transylvanian Homeland Studies\}, 22/1.). 
Wirth-Poelchau, L. (1990). Die Leichengedichte auf den Kronstädter Stadtpfarrer Marcus Fronius (1713) (1. Theil). Ein Beitrag zur Person des Verstorbenen, zu den Gedichten und den Dichtern [Burial SendOff Poems in memorial Marcus Fronius Pastor of Brasov (1713), Memoir about the Departed, his poems and poetry]. In: Zeitschrift für Siebenbürgische Landeskunde [Transylvanian Homeland Studies], Heft 1, pp. 39-61.

Open Access. This is an open-access article distributed under the terms of the Creative Commons Attribution 4.0 International License (https://creativecommons.org/licenses/by/4.0/), which permits unrestricted use, distribution, and reproduction in any medium, provided the original author and source are credited, a link to the CC License is provided, and changes - if any - are indicated. (SID_1) 